\title{
Preparation of anthracene-based tetraperimidine hexafluoro- phosphate and selective recognition of chromium(III) ions
}

\author{
Qing-Xiang Liu“, Feng Yang, Zhi-Xiang Zhao, Shao-Cong Yu and Yue Ding
}

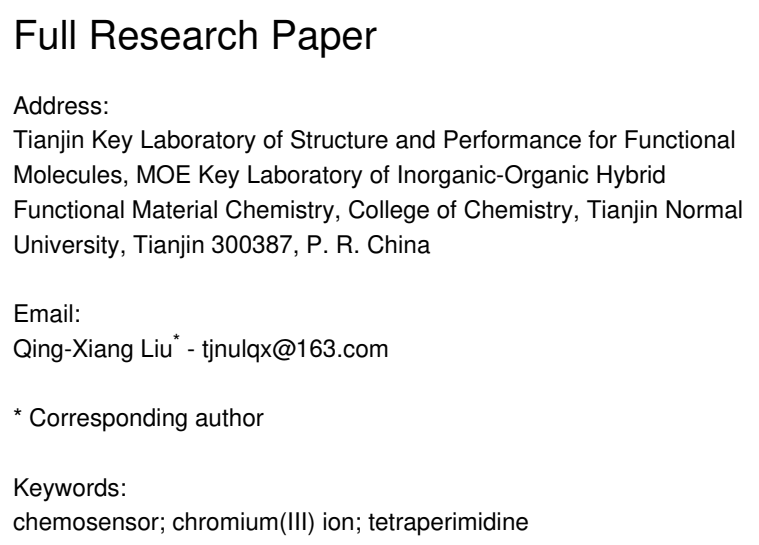

Beilstein J. Org. Chem. 2019, 15, 2847-2855.

doi:10.3762/bjoc. 15.278

Received: 02 August 2019

Accepted: 02 November 2019

Published: 25 November 2019

Associate Editor: P. J. Skabara

() 2019 Liu et al.; licensee Beilstein-Institut.

License and terms: see end of document.

\begin{abstract}
A novel anthracene-based tetraperimidine hexafluorophosphate $\mathbf{3}$ was prepared, and its structure was determined through $\mathrm{X}$-ray analysis, HRMS as well as ${ }^{1} \mathrm{H}$ and ${ }^{13} \mathrm{C}$ NMR spectroscopy. In the cationic moiety of $\mathbf{3}$, two ( $N$-ethylperimidinyl- $\left.\mathrm{C}_{2} \mathrm{H}_{4}\right)_{2} \mathrm{NCH}_{2-}$ arms were attached to the 9- and 10-positions of anthracene. In addition, compound $\mathbf{3}$ was used as a chemosensor to research the ability to recognize $\mathrm{Cr}^{3+}$ through fluorescence and UV titrations, HRMS, as well as ${ }^{1} \mathrm{H}$ NMR and IR spectroscopy. The results indicate that $\mathbf{3}$ is an effective chemosensor for $\mathrm{Cr}^{3+}$.
\end{abstract}

\section{Introduction}

Fluorescent chemosensors are an attractive and efficient tool for the detection of metal ions in environmental and biological science because of their high sensitivity, selectivity, and simple usage [1-8]. Among metal ions, the detection of $\mathrm{Cr}^{3+}$ ions occupies an important position. Chromium(III) is an essential microelement for humans and animals, and it plays an important role in glucose and lipid metabolism in the body $[9,10]$. The deficiency of chromium(III) in the human body leads to various diseases, such as diabetes as well as autoimmune and cardiovascular diseases [11]. On the other hand, the excessive incorporation of chromium(III) is toxic to humans, and can cause cancer through the oxidation of DNA and some proteins [12-14]. Therefore, the detection of chromium(III) has a vital practical significance for human health monitoring.
In recent years, some fluorescent chemosensors for the detection of chromium(III) have been developed [15-23]. Generally, chemosensors with fluorescence enhancement are more efficient than fluorescence turn-off chemosensors [24-29] because the paramagnetic nature of chromium(III) can cause fluorescence quenching of the fluorophore via the enhancement of spin-orbit coupling [30-35]. So far, only a few successful examples of fluorescence enhancement sensors for $\mathrm{Cr}^{3+}$ have been reported [36-40]. Thus, developing new and effective fluorescence turn-on chemosensors for $\mathrm{Cr}^{3+}$ is necessary.

In the process of our research, a tetradentate compound bearing a fluorophore aroused our interest. In this paper, we report the synthesis of a novel anthracene-based tetraperimidine hexa- 
fluorophosphate $\mathbf{3}$, and its structure was determined by X-ray analysis as well as ${ }^{1} \mathrm{H}$ and ${ }^{13} \mathrm{C}$ NMR spectroscopy. Particularly, compound $\mathbf{3}$ was tested as a chemosensor for the recognition of $\mathrm{Cr}^{3+}$ through fluorescence, UV, IR, and ${ }^{1} \mathrm{H}$ NMR spectroscopy along with HRMS. Altogether, the results indicate the utility of $\mathbf{3}$ as an effective chemosensor for $\mathrm{Cr}^{3+}$.

\section{Results and Discussion}

\section{Synthesis and characterization of 3}

As displayed in Scheme 1, paraformaldehyde was reacted with anthracene to give 9,10-di(chloromethyl)anthracene in $82 \%$ yield, which reacted further with $\mathrm{HN}\left(\mathrm{CH}_{2} \mathrm{CH}_{2} \mathrm{OH}\right)_{2}$ to form 9,10-bis $\{[N, N$-di(2-hydroxyethyl)amino $]$ methyl $\}$ anthracene (1) with a yield of 58\% [41]. Compound $\mathbf{1}$ was then treated with $\mathrm{SOCl}_{2}$ to generate 9,10 -bis $\{[N, N$-di(2-chloroethyl)amino $]-$ methyl anthracene (2) in $75 \%$ yield, which reacted with 1-ethylperimidine in the presence of KI to afford the analogous iodide salt to tetraperimidine 3. Subsequently, an anion exchange reaction with $\mathrm{NH}_{4} \mathrm{PF}_{6}$ was performed to generate tetraperimidine hexafluorophosphate 3 with a yield of $85 \%$. Compound $\mathbf{3}$ was stable to heat, moisture, and air, and it had a good solubility in DCM, DMSO, and $\mathrm{CH}_{3} \mathrm{CN}$. In turn, it had a poor solubility in benzene and petroleum ether. In the ${ }^{1} \mathrm{H}$ NMR spectrum of 3 , the proton signal corresponding to the $\mathrm{NCHN}$ motif in perimidine was present at $\delta=8.69 \mathrm{ppm}$ [42].

\section{Structure elucidation of compound $\mathbf{3}$}

As can be seen in the crystal structure of $\mathbf{3}$ in Figure 1, the cationic moiety of the complex contained two ( $N$-ethylperimidinyl- $\left.\mathrm{C}_{2} \mathrm{H}_{4}\right)_{2} \mathrm{NCH}_{2}-$ arms attached to the 9- and 10-positions of anthracene, and the dihedral angle between two perimidine units of each arm was determined to be 18.1(4) ${ }^{\circ}$. Two of the four perimidine groups were parallel to the anthracene plane, with intramolecular $\pi-\pi$ interactions [43] being present in this setup (with a face-to-face distance of 3.566(1) $\AA$ between perimidine and anthracene and a center-to-center distance of 3.664(4) ^). The bond distances C(3)-N(1) and C(3)-N(2) were $1.310(5)$ and $1.315(5) \AA$ and the dihedral angles $\mathrm{N}(2)-\mathrm{C}(3)-\mathrm{N}(1)$ and $\mathrm{N}(4)-\mathrm{C}(18)-\mathrm{N}(5)$ were $125.2(3)$ and $124.3(4)^{\circ}$ [42]. Further, a 1D polymeric chain of 3 monomers was generated through intermolecular $\pi-\pi$ interactions between perimidine moieties (with a face-to-face distance of 3.558(4) $\AA$ and a center-to-center distance of 3.566(1) $\AA$ ), as shown in Supporting Information File 1, Figure S1a. Besides, a 2D supramolecular layer was formed by the $1 \mathrm{D}$ supramolecular chains through two types of $\mathrm{C}-\mathrm{H} \cdots \mathrm{F}$ hydrogen bonds, namely

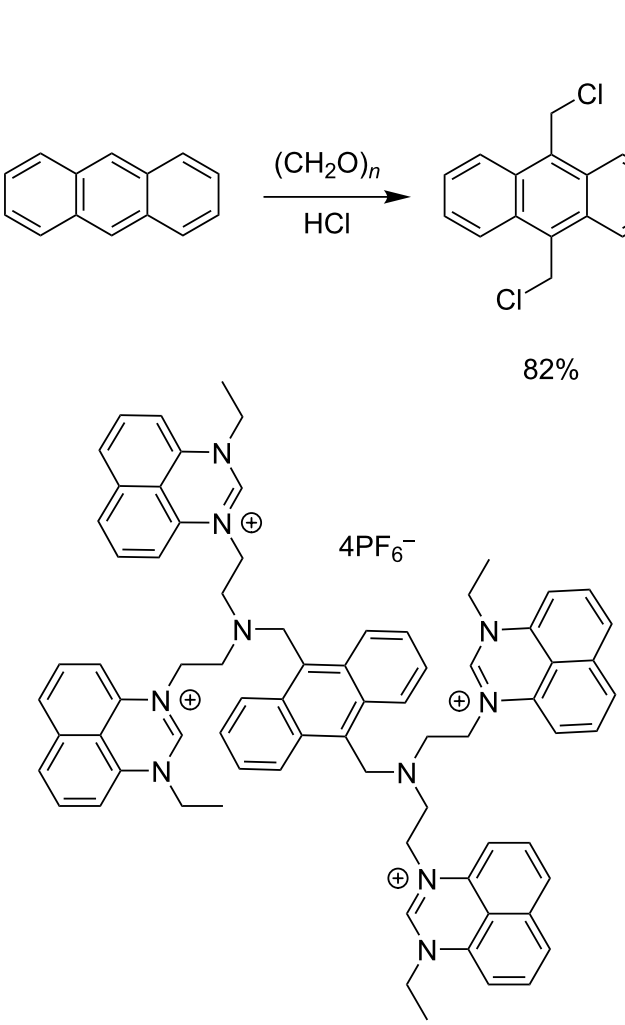

$3(85 \%)$

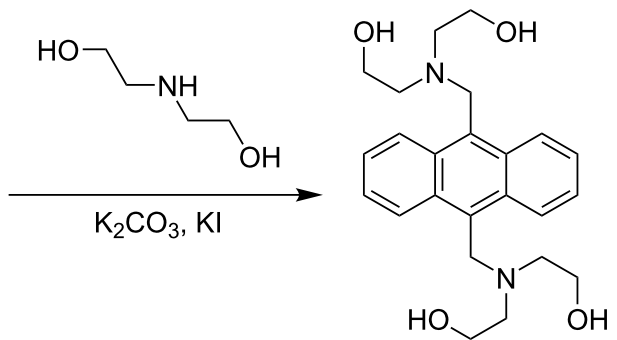

$1(58 \%)$<smiles>[3H][14CH2]O[SeH3]</smiles>

(i)<smiles>CCN1C=Nc2cccc3cc(Cl)cc1c23</smiles>

(ii) $\mathrm{NH}_{4} \mathrm{PF}_{6}$ 


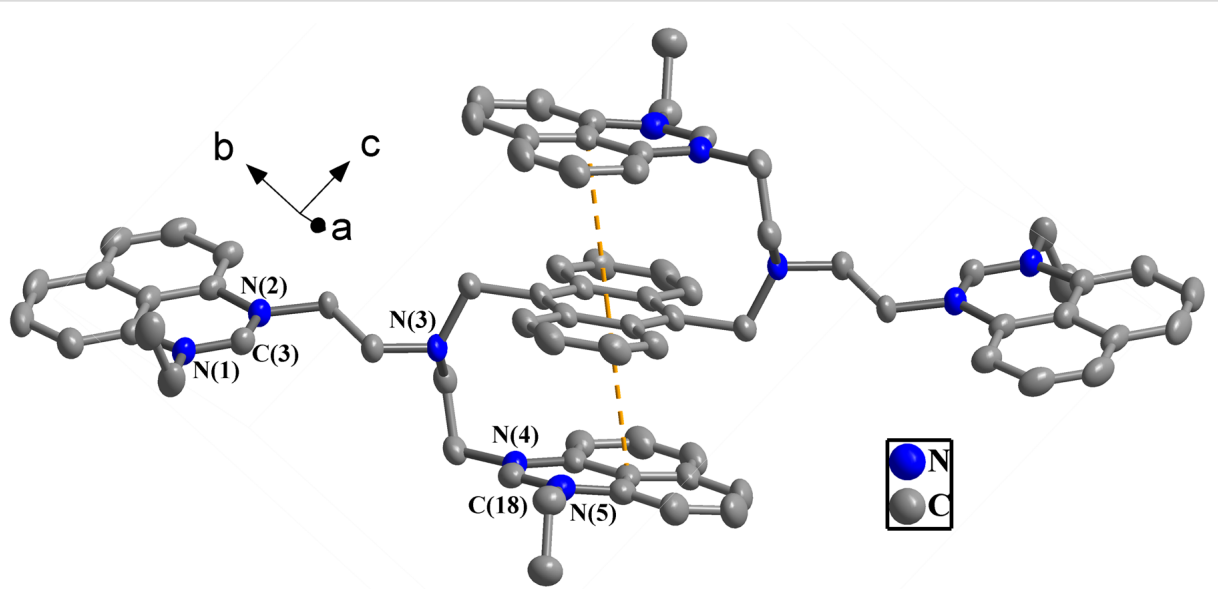

Figure 1: View of the molecular structure of the cationic moiety of 3 in the crystal. Selected bond angles and lengths are $N(2)-C(3)-N(1): 125.2(3)^{\circ}$; $\mathrm{N}(5)-\mathrm{C}(18)-\mathrm{N}(4): 124.3(4)^{\circ} ; \mathrm{C}(3)-\mathrm{N}(1): 1.310(5) \AA \AA$; and $\mathrm{C}(3)-\mathrm{N}(2): 1.315(5) \AA$.

$\mathrm{C}(3)-\mathrm{H}(3 \mathrm{~A}) \cdots \mathrm{F}(2)$ and $\mathrm{C}(17)-\mathrm{H}(17 \mathrm{~A}) \cdots \mathrm{F}(2)$ interactions (Supporting Information File 1, Figure $\mathrm{S} 1 \mathrm{~b})$.

\section{Chemosensing of cations by 3}

Compound $\mathbf{3}$ was employed as a host to study its ability to detect some cations through fluorescence and UV titrations in $\mathrm{CH}_{3} \mathrm{CN} / \mathrm{DMSO}, 9: 1, \mathrm{v} / \mathrm{v}$ at room temperature. In its free form, three emission bands at 402, 423, and $447 \mathrm{~nm}$ were observed at $c=5.0 \cdot 10^{-6} \mathrm{M}$, which were ascribed to the emission of anthracene (Figure 2). When adding 30 equiv of $\mathrm{K}^{+}, \mathrm{Na}^{+}, \mathrm{Li}^{+}$, $\mathrm{Ag}^{+}, \mathrm{NH}_{4}{ }^{+}, \mathrm{Zn}^{2+}, \mathrm{Cd}^{2+}, \mathrm{Ca}^{2+}, \mathrm{Ni}^{2+}, \mathrm{Pb}^{2+}, \mathrm{Cu}^{2+}, \mathrm{Co}^{2+}, \mathrm{Al}^{3+}$, $\mathrm{Hg}^{+}, \mathrm{Hg}^{2+}, \mathrm{Rh}^{3+}, \mathrm{Ir}^{3+}, \mathrm{Cr}^{2+}, \mathrm{Ga}^{3+}, \mathrm{Ru}^{3+}$, and $\mathrm{Fe}^{3+}$, respective$1 y$, the intensities of the emission bands did not change significantly. However, a strong enhancement of the emission intensity in the region of 388-500 $\mathrm{nm}$ was observed after the addition of 30 equiv of $\mathrm{Cr}^{3+}$. Moreover, the absorption peak of $\mathbf{3}$ at $258 \mathrm{~nm}\left(\varepsilon=3.5 \cdot 10^{3} \mathrm{~mol}^{-1} \cdot \mathrm{dm}^{3} \cdot \mathrm{cm}^{-1}\right)$ did not exhibit any remarkable response to the addition of these cations, except for $\mathrm{Cr}^{3+}\left(\varepsilon=1.1 \cdot 10^{4} \mathrm{~mol}^{-1} \cdot \mathrm{dm}^{3} \cdot \mathrm{cm}^{-1}\right)$ as a result of $3 \cdot \mathrm{Cr}^{3+}$ formation (Supporting Information File 1, Figure S2). These results show that $\mathbf{3}$ is able to effectively distinguish $\mathrm{Cr}^{3+}$ from other cations.

To further investigate the recognition of $\mathrm{Cr}^{3+}$ by $\mathbf{3}$, fluorescence titrations were carried out (Figure 3 ). The fluorescence intensity of $\mathbf{3}$ in the region of $388-500 \mathrm{~nm}$ increased gradually upon addition of $\mathrm{Cr}^{3+}\left(c=5.0 \cdot 10^{-6} \mathrm{M}\right)$. Titration was continued until no more notable changes in emission intensity occurred. In the inset of Figure 3, it is shown that when the molar ratio of $\mathrm{Cr}^{3+}$ to 3, i.e., $c_{\mathrm{Cr}} 3+/ c_{3}$, was below $1: 1$, fluorescence intensity enhanced sharply. However, when the molar ratio exceeded 1:1, the rate of fluorescence enhancement gradually slowed down until no more changes were noticeable. The limit of detection (LOD) was calculated to be $2.33 \cdot 10^{-7} \mathrm{M}$ (Supporting Informa- tion File 1, Figure S3). This value is analogous to the lowest corresponding value that has been reported in the literature $\left(9.40 \cdot 10^{-7}-5.55 \cdot 10^{-6} \mathrm{M}\right)$ [44-46]. The association constant $K_{\mathrm{SV}}$ was calculated to be $6.6 \cdot 10^{4} \mathrm{M}^{-1}(R=0.998)$ for $3 \cdot \mathrm{Cr}^{3+}$ using Equation 1 (Supporting Information File 1, Figure S4) [47].

$$
F / F_{0}=1+K_{\mathrm{SV}} \cdot c_{\mathrm{Cr} 3+}
$$

In Equation 1, the fluorescence intensities of $\mathbf{3}$ in the presence of $\mathrm{Cr}^{3+}$ and in its free form are represented by $F$ and $F_{0}$.

In the UV titration experiments, the absorption band in the region of 240-265 $\mathrm{nm}$ increased gradually upon addition of $\mathrm{Cr}^{3+}$ to a solution of $\mathbf{3}\left(c=5.0 \cdot 10^{-6} \mathrm{M}\right)$ in $\mathrm{CH}_{3} \mathrm{CN} / \mathrm{DMSO}, 9: 1$, $\mathrm{v} / \mathrm{v}$ at room temperature (Supporting Information File 1, Figure S5). To evaluate the stability of $3 \cdot \mathrm{Cr}^{3+}$, the stability constant $K$ for the complex was computed as $8.23 \cdot 10^{4} \mathrm{M}^{-1}(R=0.999)$ at $258 \mathrm{~nm}$ using Equation 2 (Supporting Information File 1, Figure S6) [48-51].

$$
A_{0} /\left(A_{0}-A\right)=\left[\varepsilon_{\mathrm{r}} /\left(\varepsilon_{\mathrm{r}}-\varepsilon_{\mathrm{c}}\right)\right] \cdot\left(1 / K c_{3}+1\right)
$$

In Equation 2, the absorbances of $\mathbf{3}$ in presence and absence of $\mathrm{Cr}^{3+}$ are represented as $A_{0}$ and $A$. The discrepancy in absorbance in the presence and absence of $\mathrm{Cr}^{3+}$ is represented through the expression $A_{0}-A$ (i.e., $\Delta A$ ). The molar extinction coefficients of $\mathrm{Cr}^{3+}$ and the complex $3 \cdot \mathrm{Cr}^{3+}$ are represented by $\varepsilon_{\mathrm{r}}$ and $\varepsilon_{\mathrm{c}}$.

The complexation stoichiometry between $\mathbf{3}$ and $\mathrm{Cr}^{3+}$ was established by using Job's method (inset of Figure S5, Supporting Information File 1). When the molar fraction $(\chi)$ of $\mathbf{3}$ was 0.5 , the $\Delta A \chi$ value for $3 \cdot \mathrm{Cr}^{3+}$ reached a maximum, which indicated 


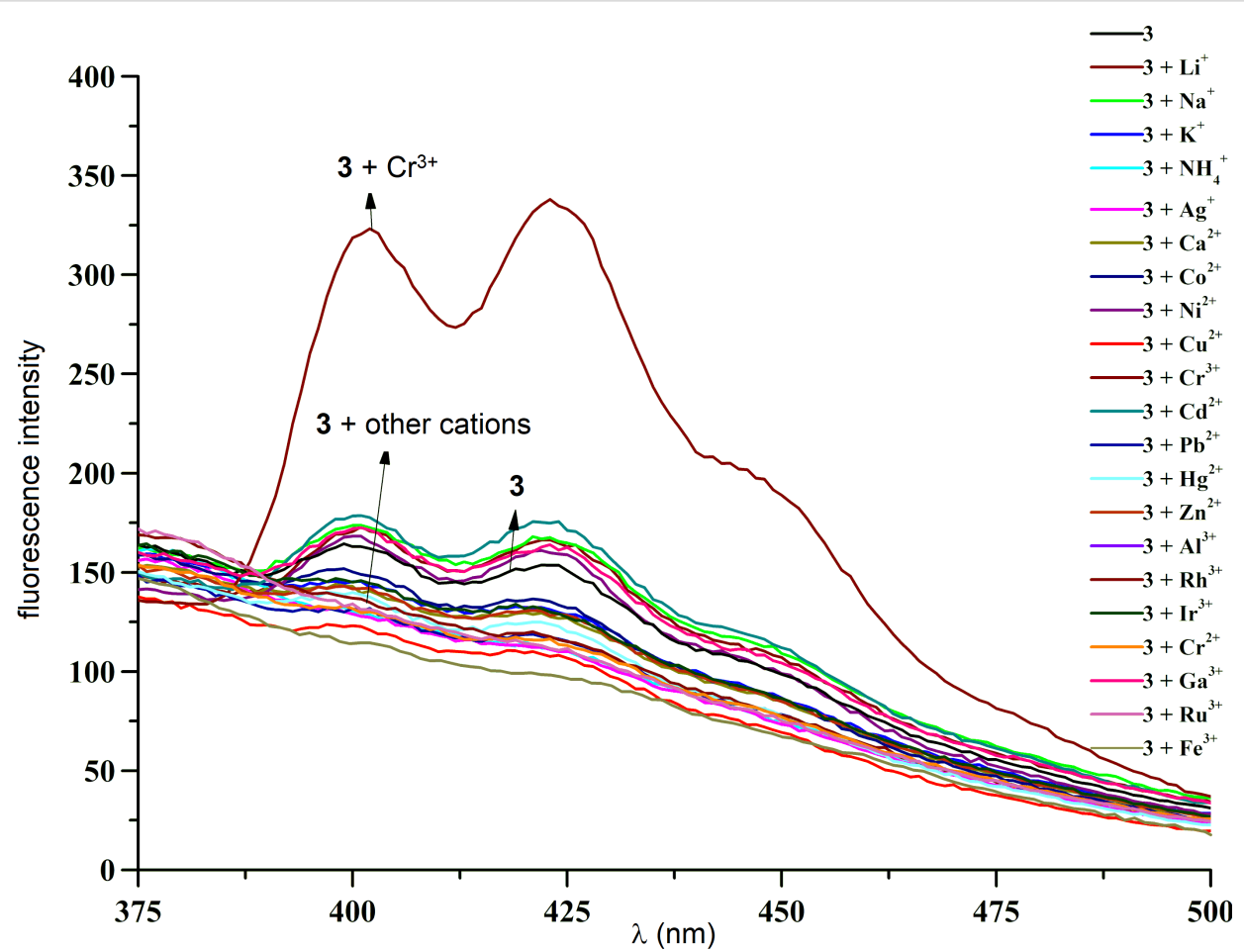

Figure 2: Fluorescence spectra of $3\left(c=5.0 \cdot 10^{-6} \mathrm{M}\right)$ upon addition of 30 equiv of salts of $\mathrm{K}^{+}, \mathrm{Na}^{+}, \mathrm{Li}^{+}, \mathrm{Ag}^{+}, \mathrm{NH}_{4}^{+}, \mathrm{Zn}^{2+}, \mathrm{Cd}^{2+}, \mathrm{Ca}^{2+}, \mathrm{Ni}^{2+}, \mathrm{Pb}^{2+}, \mathrm{Cu}^{2+}$ $\mathrm{Co}^{2+}, \mathrm{Al}^{3+}, \mathrm{Cr}^{3+}, \mathrm{Hg}^{+}, \mathrm{Hg}^{2+}, \mathrm{Rh}^{3+}, \mathrm{Ir}^{3+}, \mathrm{Cr}^{2+}, \mathrm{Ga}^{3+}, \mathrm{Ru}^{3+}$, and $\mathrm{Fe}^{3+}$, respectively $\left(c=1.5 \cdot 10^{-4} \mathrm{M}\right)$ in $\mathrm{CH}_{3} \mathrm{CN} / \mathrm{DMSO}, 9: 1, \mathrm{v} / \mathrm{v}$ at room temperature (excitation wavelength $\lambda_{\mathrm{ex}}=258 \mathrm{~nm}$ ).

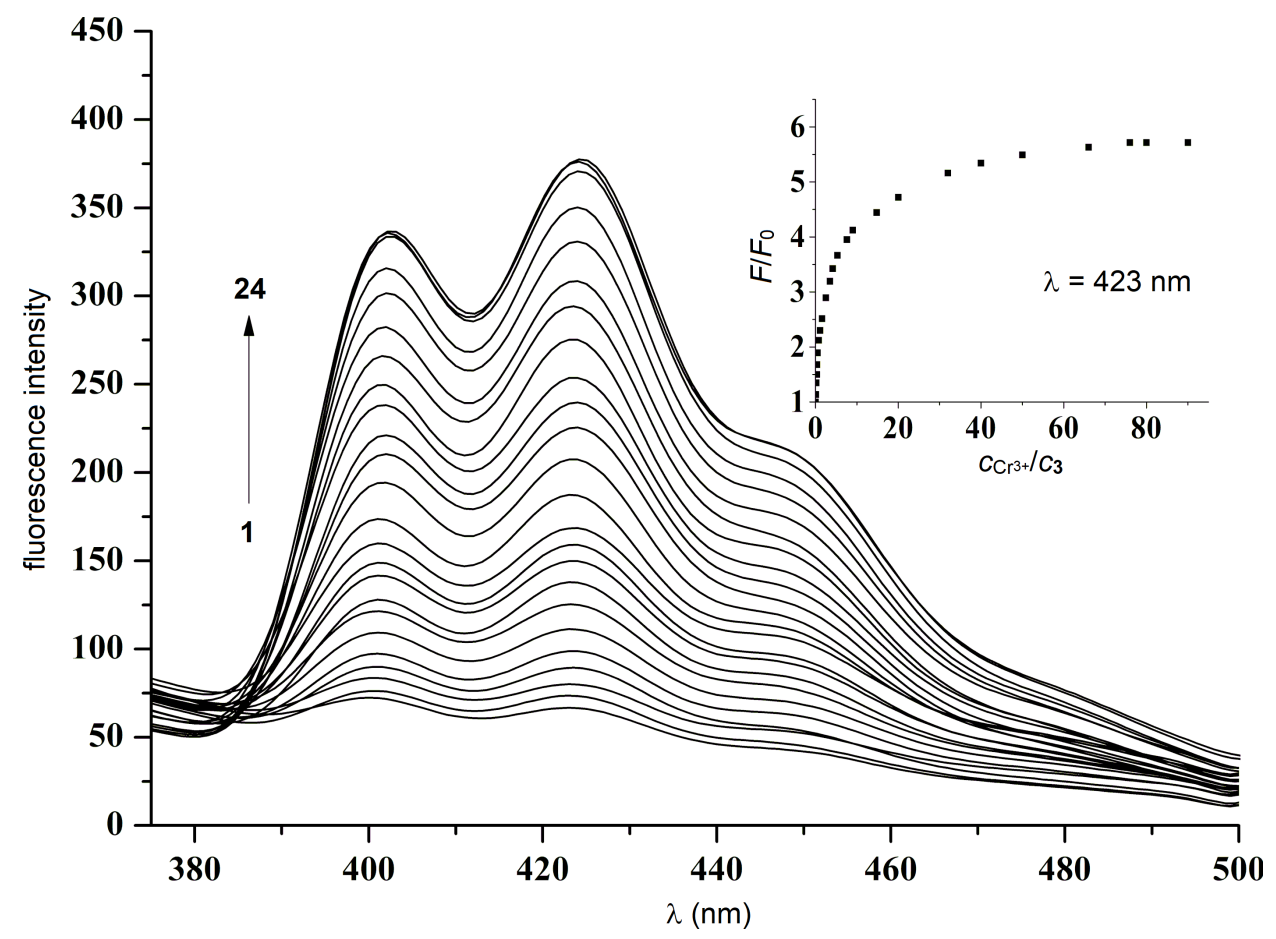

Figure 3: Fluorescence spectra of $3\left(c=5 \cdot 10^{-6} \mathrm{M}\right)$ upon addition of various amounts of $\mathrm{Cr}^{3+}$. $\mathrm{c}_{\mathrm{Cr}}{ }^{3+}$ for curves $1-24$ (from bottom to top) were (0.00, $0.04,0.08,0.16,0.24,0.35,0.49,0.67,0.80,1.00,1.45,1.85,2.30,3.70,4.50,7.00,10.00,16.00,20.00,25.00,33.00,38.00,40.00$, and $45.00) \cdot 10^{-5} \mathrm{M}\left(\lambda_{\mathrm{ex}}=258 \mathrm{~nm}\right)$. 
that the complexation stoichiometry between $\mathbf{3}$ and $\mathrm{Cr}^{3+}$ was $1: 1$ in $\mathbf{3} \cdot \mathrm{Cr}^{3+}[8,52,53]$.

To measure the selectivity of $\mathrm{Cr}^{3+}$ complexation by $\mathbf{3}$, displacement experiments were carried out (Supporting Information File 1, Figure S7). Firstly, 30 equiv of $\mathrm{Cr}^{3+}$ were added to solutions of 3 containing 30 equiv of $\mathrm{K}^{+}, \mathrm{Na}^{+}, \mathrm{Li}^{+}, \mathrm{Ag}^{+}, \mathrm{NH}_{4}{ }^{+}$, $\mathrm{Zn}^{2+}, \mathrm{Cd}^{2+}, \mathrm{Ca}^{2+}, \mathrm{Ni}^{2+}, \mathrm{Pb}^{2+}, \mathrm{Cu}^{2+}, \mathrm{Co}^{2+}, \mathrm{Al}^{3+}, \mathrm{Hg}^{+}, \mathrm{Hg}^{2+}$, $\mathrm{Rh}^{3+}, \mathrm{Ir}^{3+}, \mathrm{Cr}^{2+}, \mathrm{Ga}^{3+}, \mathrm{Ru}^{3+}$, and $\mathrm{Fe}^{3+}$, respectively. The emission intensities of the resulting mixtures were similar to that of a solution containing only 3 and $\mathrm{Cr}^{3+}$. These experimental results show that 3 can capture $\mathrm{Cr}^{3+}$ selectively while neglecting other cations, with no remarkable interference being caused in the presence of the latter.

In order to probe whether the anions of the chromium(III) salts had effects on the binding of $\mathbf{3}$ and $\mathrm{Cr}^{3+}$, other chromium(III) salts, $\mathrm{CrCl}_{3}, \mathrm{CrBr}_{3}, \mathrm{Cr}_{2}\left(\mathrm{SO}_{4}\right)_{3}, \mathrm{Cr}\left(\mathrm{NO}_{3}\right)_{3}$, and $\mathrm{Cr}(\mathrm{OAc})_{3}$, were tested. As displayed in Figure S8, Supporting Information File 1 , when 30 equiv of any of these were added to $\mathbf{3}$, similar fluorescence intensities could be detected. A reversible binding experiment was also carried out (Supporting Information File 1, Figure S9). Therein, 30 equiv of ethylenediaminetetraacetic acid (EDTA) were added to a solution of $\mathrm{Cr}^{3+}\left(c=1.5 \cdot 10^{-4} \mathrm{M}\right)$ and $3\left(c=5.0 \cdot 10^{-6} \mathrm{M}\right)$, which led to a reduction of the fluorescence intensity at $388-500 \mathrm{~nm}$. This reduced fluorescent intensity was analogous to that of free $\mathbf{3}$, displaying that $\mathbf{3}$ was regenerated in its uncomplexed form. When $\mathrm{Cr}^{3+}$ was added anew, the fluorescent intensity increased again. These results show that the binding process of $\mathbf{3}$ and $\mathrm{Cr}^{3+}$ has good reversibility and highlights the regenerative capacity of the $3 \cdot \mathrm{Cr}^{3+}$ complex.

\section{Interactions between $\mathbf{3}$ and $\mathrm{Cr}^{3+}$}

Looking at the structural characteristics of $\mathbf{3}$, the nitrogen atoms of the tertiary amines, and the $\pi$ systems, were most likely the binding sites for $\mathrm{Cr}^{3+}$ through $\mathrm{Cr}^{3+} \ldots \mathrm{N}$ and $\mathrm{Cr}^{3+} \ldots \pi$ interactions (Scheme 2). In order to obtain further information on the binding pattern between 3 and $\mathrm{Cr}^{3+},{ }^{1} \mathrm{H}$ NMR titration studies were done in DMSO- $d_{6}$. The spectra are depicted in Figure 4.

Upon incremental addition of $\mathrm{Cr}^{3+}$ to $\mathbf{3}$ (from 0.0 to 1.0 equiv), the proton signals a and $\mathrm{b}$, corresponding to anthracene, shifted downfield by $0.03 \mathrm{ppm}$ in total while the proton signals $\mathrm{f}$ and 1 , corresponding to perimidine, shifted downfield between 0.02 and $0.07 \mathrm{ppm}$. Further, the proton signals $\mathrm{c}, \mathrm{d}$, and e of the $\mathrm{CH}_{2}$ groups beside perimidine and anthracence shifted downfield by $0.03 \mathrm{ppm}$ while the chemical shifts of other protons did not undergo visible changes. These experimental results suggest $\mathrm{Cr}^{3+} \ldots \pi$ interactions as the most likely binding mode between $\mathrm{Cr}^{3+}$ and $\mathbf{3}$, as illustrated in Scheme 2. In $\mathbf{3}$, each perimidine moiety is electron-rich due to the existence of a $\pi_{13}^{15}$ bond (Sup-

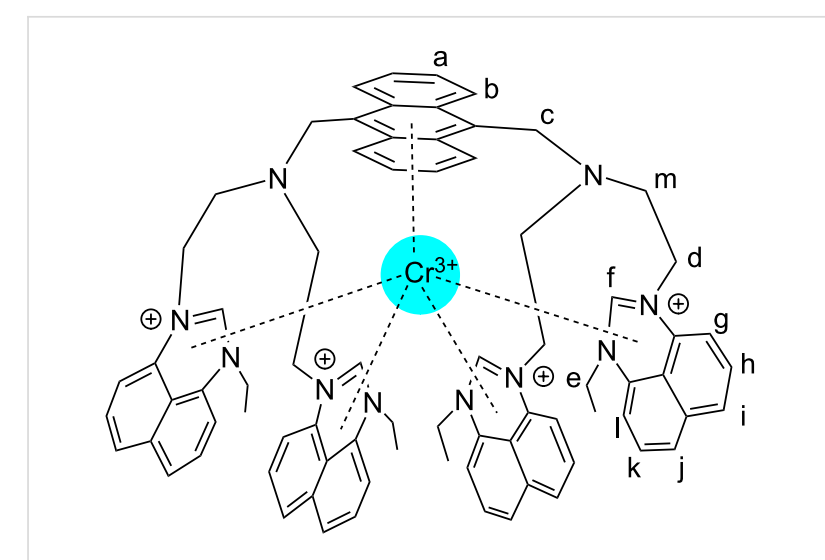

Scheme 2: Illustration of interactions between 3 and $\mathrm{Cr}^{3+}$ in $\mathbf{3} \cdot \mathrm{Cr}^{3+}$.

porting Information File 1, Figure S10), and the strong affinity of the $\pi$ system of each perimidine and the anthracene motif towards $\mathrm{Cr}^{3+}$ resulted in the facile formation of $\mathrm{Cr}^{3+} \ldots \pi$ interactions. It is worth noting that $\mathrm{Cr}^{3+} \ldots \pi$ interactions are not uncommon, and they have been reported in diaryl chromium complexes $[54,55]$. Besides, $\mathrm{Cr}^{3+} \ldots \mathrm{N}$ interactions in $\mathbf{3} \cdot \mathrm{Cr}^{3+} \mathrm{did}$ not appear relevant for complexation. The reasons were that (1) the signal $\mathrm{m}$, corresponding to the $\mathrm{CH}_{2}$ fragment beside the nitrogen atom of the tertiary amine, did not shift discernibly during ${ }^{1} \mathrm{H}$ NMR titration; (2) if the tertiary amine groups coordinated to one $\mathrm{Cr}^{3+}$ ion each, a 1:2 binding mode would have been determined for $3 \cdot \mathrm{Cr}^{3+}$; and (3) from the molecular structure of $\mathbf{3}$, due to the distance, it is spatially impossible that one $\mathrm{Cr}^{3+}$ ion is bound by both tertiary amine functions at the same time. All these arguments underline the absence of $\mathrm{Cr}^{3+} \ldots \mathrm{N}$ interactions. The selectivity of the $\mathrm{Cr}^{3+}$ binding process by 3 may be mainly due to the metal ion's size, which could have been particularly suitable for coordination between anthracence and four perimidine groups, whereas the sizes of other metal cations were unsuitable. The fact that chromium(III) is triply charged may not have been a key influence because otherwise, other metal cations $\mathrm{M}^{3+}$ would have also been bound by $\mathbf{3}$.

Furthermore, looking at Figure 4, the proton signals a to 1 remained unchanged after 1 equiv of $\mathrm{Cr}^{3+}$ had been added to 3 . That is, the signals in spectra (iv) and (v) have the same positions. This again illustrates 1:1 complexation between $\mathbf{3}$ and $\mathrm{Cr}^{3+}$. This result is consistent with the conclusions obtained from Job's plot. In addition, HRMS analysis of $\mathbf{3} \cdot \mathrm{Cr}^{3+}$ (Supporting Information File 1, Figure S11) produced a distinctive signal at $m / z=587.1086$, matching $\left(3 \cdot \mathrm{Cr}^{3+}\right) / 3$, again indicating 1:1 complexation. In the IR spectra of $\mathbf{3}$ and $\mathbf{3} \cdot \mathrm{Cr}^{3+}$ (Supporting Information File 1, Figure S12), the $\mathrm{C}-\mathrm{C}$ absorption band of a benzene moiety in 3 shifted from 1170 to $1185 \mathrm{~cm}^{-1}$ upon complexation, and the $\mathrm{C}=\mathrm{N}$ absorption band at $1664 \mathrm{~cm}^{-1}$ shifted to a value of $1672 \mathrm{~cm}^{-1}$. 


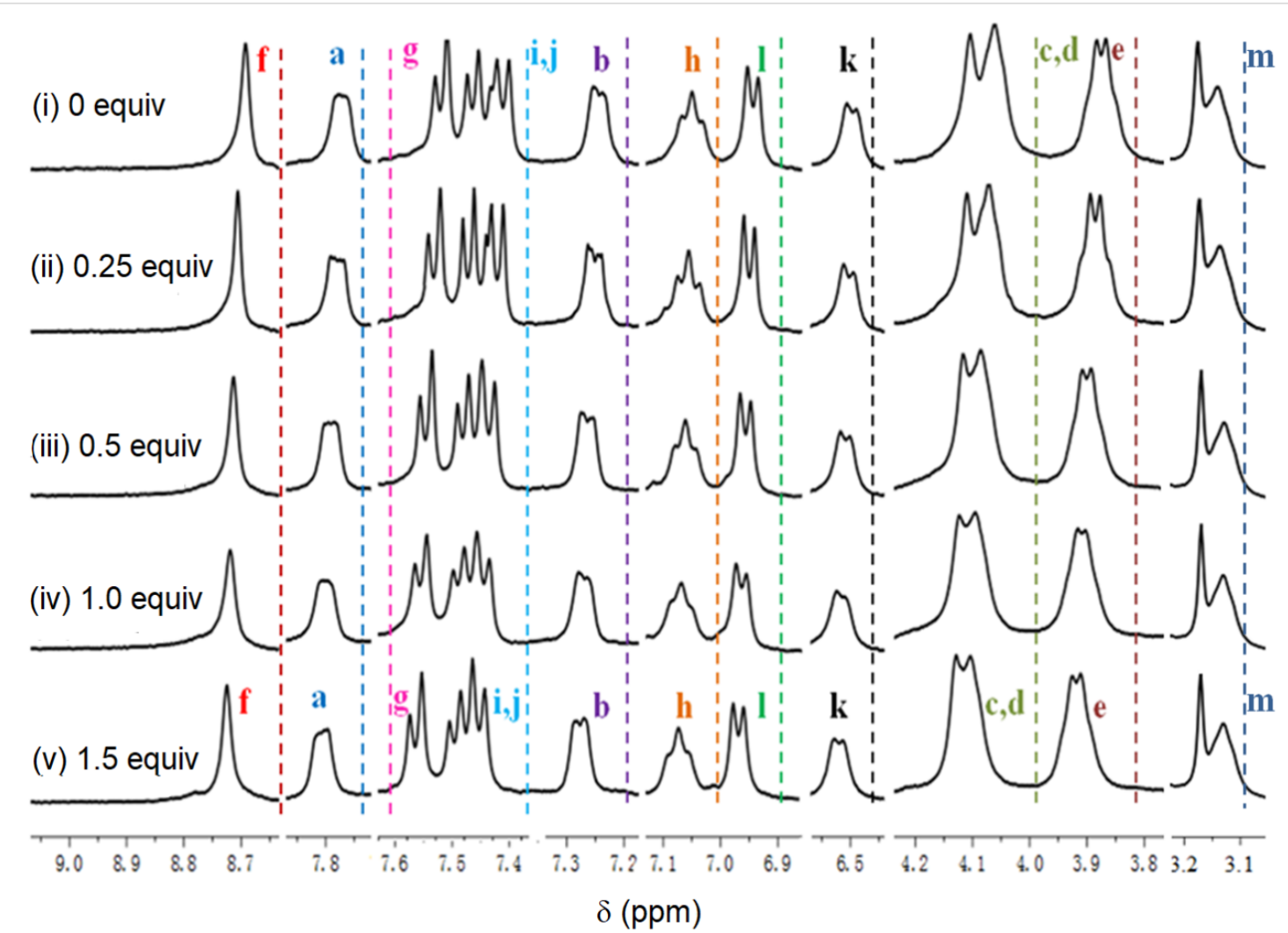

Figure 4: ${ }^{1} \mathrm{H}$ NMR spectra of 3 in the presence of $\mathrm{Cr}^{3+}$ in DMSO-d $d_{6}$. (i) 3. (ii) $3+0.25$ equiv of $\mathrm{Cr}^{3+}$. (iii) $3+0.5$ equiv of $\mathrm{Cr}^{3+}$. (iv) $3+1 \mathrm{equiv}$ of $\mathrm{Cr}^{3+}$ (v) $3+1.5$ equiv of $\mathrm{Cr}^{3+}$.

\section{Conclusion}

In summary, a new anthracene-based tetraperimidine hexafluorophosphate 3 was prepared, and its structure was determined through $\mathrm{X}$-ray analysis and ${ }^{1} \mathrm{H}$ and ${ }^{13} \mathrm{C}$ NMR spectroscopy. Compound $\mathbf{3}$ was proved to be a highly sensitive and selective chemosensor for $\mathrm{Cr}^{3+}$, and it can effectively distinguish $\mathrm{Cr}^{3+}$ from other cations through fluorescence enhancement. Thus, complex $\mathbf{3}$ may have potential value for the application as a $\mathrm{Cr}^{3+}$ detector.

\section{Experimental \\ Materials and instruments}

The solvents and chemicals used for synthesis and analysis were analytical grade and obtained commercially. A RF-5301PC fluorescence spectrophotometer (Shimadzu) was used to record fluorescence spectra at room temperature. The excitation and emission slits were set to $10 \mathrm{~nm}$. UV-vis absorption spectra were recorded at room temperature using a JASCOV570 spectrometer. A Varian spectrometer was employed to record ${ }^{1} \mathrm{H}$ and ${ }^{13} \mathrm{C}$ NMR spectra. A Perkin-Elmer $2400 \mathrm{C}$ Elemental Analyzer was employed for elemental analyses. IR spectra were measured with a PerkinElmer Spectrum 100 FT-IR spectrophotometer. A Q-TOF LC/MS (Agilent) and a VG ZABHS (VG) mass spectrometer were applied for HRMS analysis.
Melting points were recorded employing a Boetius Block apparatus.

\section{Analytical data}

Synthesis of 1-ethylperimidine: Through a dropping funnel, a solution of perimidine $(1.43 \mathrm{~g}, 8.5 \mathrm{mmol})$ in dry THF $(30 \mathrm{~mL})$ was added to a suspension of $\mathrm{NaH}(0.479 \mathrm{~g}, 20 \mathrm{mmol})$ in dry THF $(10 \mathrm{~mL})$, followed by stirring at room temperature for $1 \mathrm{~h}$. Subsequently, bromoethane ( $1.308 \mathrm{~g}, 12 \mathrm{mmol})$ was added to the suspension, and the mixture was reacted for $24 \mathrm{~h}$ at ambient temperature. After filtration, the solvent was removed at reduced pressure, and water $(50 \mathrm{~mL})$ was added to the residue. This was extracted with $\mathrm{CHCl}_{3}(3 \times 20 \mathrm{~mL})$, the organic layer was rinsed with water $(3 \times 30 \mathrm{~mL})$, and dried over anhydrous $\mathrm{MgSO}_{4}$. 1-Ethylperimidine was obtained as a yellow-green solid $(0.825 \mathrm{~g}, 49 \%)$ after removal of the solvent. mp 198-200 ${ }^{\circ} \mathrm{C}$; ${ }^{1} \mathrm{H}$ NMR (400 MHz, DMSO- $d_{6}$ ) $\delta 1.49$ (t, $\left.J=7.2 \mathrm{~Hz}, 3 \mathrm{H}, \mathrm{CH}_{3}\right), 4.27$ (q, $\left.J=7.2 \mathrm{~Hz}, 2 \mathrm{H}, \mathrm{CH}_{2}\right)$, $7.31(\mathrm{~d}, J=8.8 \mathrm{~Hz}, 2 \mathrm{H}, \operatorname{Ar} H), 7.76(\mathrm{~d}, J=8.8 \mathrm{~Hz}, 2 \mathrm{H}$, $\operatorname{ArH}), 8.04$ (s, 1H, ArH), 8.25 (s, 1H, ArH), 9.73 ppm (s, 1H, $\mathrm{NCHN})$.

Synthesis of 9,10-bis(chloromethyl)anthracene: A suspension of paraformaldehyde $(6.155 \mathrm{~g}, 205 \mathrm{mmol})$ and anthracene 
$(17.823 \mathrm{~g}, 100 \mathrm{mmol})$ in a mixture of acetic acid $(50 \mathrm{~mL})$ and hydrochloric acid $(36 \%, 20 \mathrm{~mL})$ was heated to $100{ }^{\circ} \mathrm{C}$ for $5 \mathrm{~h}$. Then, $200 \mathrm{~mL}$ of water were added to precipitate a yellow solid. After filtration, 9,10-bis(chloromethyl)anthracene was obtained as a yellow powder $(22.452 \mathrm{~g}, 82 \%) . \mathrm{mp} 246-248{ }^{\circ} \mathrm{C} ;{ }^{1} \mathrm{H} \mathrm{NMR}$ $\left(400 \mathrm{MHz}, \mathrm{CDCl}_{3}\right) \delta 5.62\left(\mathrm{~s}, 4 \mathrm{H}, \mathrm{CH}_{2}\right), 7.68(\mathrm{q}, J=1.6 \mathrm{~Hz}, 4 \mathrm{H}$, $\mathrm{ArH}), 8.41 \mathrm{ppm}(\mathrm{q}, J=1.6 \mathrm{~Hz}, 4 \mathrm{H}, \operatorname{Ar} H) ;{ }^{13} \mathrm{C} \mathrm{NMR}(100 \mathrm{MHz}$, $\left.\mathrm{CDCl}_{3}\right) \delta 130.2(\mathrm{ArC}), 129.7(\mathrm{ArC}), 126.7(\mathrm{ArC}), 124.3(\mathrm{ArC})$, $67.1 \mathrm{ppm}\left(\mathrm{CH}_{2}\right)$.

Synthesis of 9,10-bis $\{[N, N$-di(2-hydroxyethyl)amino]methyl \}anthracene (1): A suspension of diethanolamine $(9.988 \mathrm{~g}, 95 \mathrm{mmol})$ and $\mathrm{K}_{2} \mathrm{CO}_{3}(25.015 \mathrm{~g}, 181 \mathrm{mmol})$ in $100 \mathrm{~mL}$ of $\mathrm{CH}_{3} \mathrm{CN} / \mathrm{CHCl}_{3}, 1: 1$, v/v was stirred under reflux for 1 h. Subsequently, 9,10-bis(chloromethyl)anthracene (8.255 g, $30 \mathrm{mmol})$ and $\mathrm{KI}(0.914 \mathrm{~g}, 5.5 \mathrm{mmol})$ were added to the solution, and the mixture was reacted for $30 \mathrm{~h}$ at $35^{\circ} \mathrm{C}$. Then, the solvent was evaporated in vacuo to give a yellow oil. After rinsing with water, a yellow solid, 9,10-bis $\{[N, N$-di(2-hydroxyethyl)amino]methyl \}anthracene (1), was obtained (7.189 g, 58\%). mp $\left.153-155{ }^{\circ} \mathrm{C} ;{ }^{1} \mathrm{H} \mathrm{NMR} \mathrm{(400} \mathrm{MHz,} \mathrm{CDCl}_{3}\right) \delta 1.96(\mathrm{~s}$, $4 \mathrm{H}, \mathrm{OH}), 2.77\left(\mathrm{t}, J=5.3 \mathrm{~Hz}, 8 \mathrm{H}, \mathrm{CH}_{2}\right), 3.43(\mathrm{t}, J=5.3 \mathrm{~Hz}, 8 \mathrm{H}$, $\left.\mathrm{CH}_{2}\right), 4.74\left(\mathrm{~s}, 4 \mathrm{H}, \mathrm{CH}_{2}\right), 7.55(\mathrm{q}, J=3.3 \mathrm{~Hz}, 4 \mathrm{H}, \mathrm{Ar} H)$, $8.51 \mathrm{ppm}(\mathrm{q}, J=3.3 \mathrm{~Hz}, 4 \mathrm{H}, \operatorname{ArH}) ;{ }^{13} \mathrm{C} \mathrm{NMR}(100 \mathrm{MHz}$, $\left.\mathrm{CDCl}_{3}\right) \delta 130.9(\mathrm{ArC}), 130.7(\mathrm{ArC}), 125.8(\mathrm{ArC}), 125.1(\mathrm{ArC})$, $59.8\left(\mathrm{CH}_{2}\right), 56.1\left(\mathrm{CH}_{2}\right), 51.6 \mathrm{ppm}\left(\mathrm{CH}_{2}\right)$.

Synthesis of 9,10-bis $\{[N, N-\operatorname{di}(2$-chloroethyl)amino $]-$ methyl\}anthracene (2): A solution of $\mathrm{SOCl}_{2}(9.517 \mathrm{~g}$, $80 \mathrm{mmol})$ in dioxane $(30 \mathrm{~mL})$ was added dropwise to a solution of compound 1 (4.125 g, $10 \mathrm{mmol})$ in dioxane $(50 \mathrm{~mL})$. The reaction mixture was stirred at $30{ }^{\circ} \mathrm{C}$ for 3 days, during which the formation of a yellow precipitate occurred. After filtration, the hydrochloride of 9,10-bis $\{[N, N$-di(2-chloroethyl)amino $]-$ methyl lanthracene (2) was obtained as a yellow solid. This was rinsed with $200 \mathrm{~mL}$ of a $\mathrm{NaOH}$ solution (20\%) for neutralization and extracted with $\mathrm{CHCl}_{3}(3 \times 60 \mathrm{~mL})$. The organic layer was washed with water $(3 \times 20 \mathrm{~mL})$ and dried over anhydrous $\mathrm{MgSO}_{4}$. A yellow powder of 9,10-bis $\{[N, N$-di(2-chloroethyl)amino]methyl \}anthracene (2) was obtained (3.67 g, 75\%) after removal of $\mathrm{CHCl}_{3}$. mp $131-133{ }^{\circ} \mathrm{C} ;{ }^{1} \mathrm{H}$ NMR $(400 \mathrm{MHz}$, DMSO- $\left.d_{6}\right) \delta 2.92\left(\mathrm{t}, J=6.7 \mathrm{~Hz}, 8 \mathrm{H}, \mathrm{CH}_{2}\right), 3.52(\mathrm{q}, J=6.1 \mathrm{~Hz}$, $\left.8 \mathrm{H}, \mathrm{CH}_{2}\right), 4.74\left(\mathrm{~s}, 4 \mathrm{H}, \mathrm{CH}_{2}\right), 7.55$ (q, $J=3.4 \mathrm{~Hz}, 4 \mathrm{H}, \mathrm{Ar} H$ ), $8.60 \mathrm{ppm}(\mathrm{q}, J=3.4 \mathrm{~Hz}, 4 \mathrm{H}, \operatorname{Ar} H) ;{ }^{13} \mathrm{C} \mathrm{NMR}(100 \mathrm{MHz}$, DMSO- $\left.d_{6}\right) \delta 130.9(\operatorname{ArC}), 130.8(\operatorname{ArC}), 126.0(\operatorname{ArC}), 125.8$ (ArC), $55.4\left(\mathrm{CH}_{2}\right), 50.3\left(\mathrm{CH}_{2}\right), 42.7 \mathrm{ppm}\left(\mathrm{CH}_{2}\right)$.

Synthesis of 3,3',3",3'"'-(((anthracene-9,10-diylbis(methylene))bis(azanetriyl))tetrakis(ethane-2,1-diyl))tetrakis(1ethyl-1H-perimidin-3-ium) tetra(hexafluorophosphate) (3): A mixture of 1-ethylperimidine $(1.177 \mathrm{~g}, 6 \mathrm{mmol}), 9,10$ - bis $\{[N, N$-di(2-chloroethyl)amino $]$ methyl $\}$ anthracene (2, $0.389 \mathrm{~g}, 0.8 \mathrm{mmol})$, and $\mathrm{KI}(0.5 \mathrm{~g}, 3 \mathrm{mmol})$ in $30 \mathrm{~mL}$ of DMF/ dioxane, $1: 4, \mathrm{v} / \mathrm{v}$ was stirred under reflux for 5 days. After the solvent was removed, water $(50 \mathrm{~mL})$ was added to the residue. This was extracted with $\mathrm{CHCl}_{3}(3 \times 30 \mathrm{~mL})$, the organic layer was washed with water $(3 \times 20 \mathrm{~mL})$, and dried over anhydrous $\mathrm{MgSO}_{4}$. A yellow powder of the tetraperimidine iodide species was gained after removal of $\mathrm{CHCl}_{3}$.

A solution of $\mathrm{NH}_{4} \mathrm{PF}_{6}(0.978 \mathrm{~g}, 6 \mathrm{mmol})$ and the tetraperimidine iodide compound $(1.309 \mathrm{~g}, 0.8 \mathrm{mmol})$ in $\mathrm{MeOH}(100 \mathrm{~mL})$ was stirred at room temperature for 3 days to give a yellow precipitate. This precipitate was collected through filtration and washed with methanol $(2 \cdot 10 \mathrm{~mL})$ to afford tetraperimidine hexafluorophosphate 3 (1.158 g, 85\%). mp 220-222 ${ }^{\circ} \mathrm{C}$; anal calcd for $\mathrm{C}_{76} \mathrm{H}_{76} \mathrm{~N}_{10} \mathrm{P}_{4} \mathrm{~F}_{24}, \mathrm{C}, 53.40 ; \mathrm{H}, 4.48 ; \mathrm{N}, 8.19 \%$; found, C, 53.53; H, 4.26; N, 8.21\%; HRESIMS $(\mathrm{m} / \mathrm{z}):\left[\mathrm{M}-2 \mathrm{PF}_{6}{ }^{-}\right]^{2+} / 2$ calcd for $\mathrm{C}_{38} \mathrm{H}_{38} \mathrm{~F}_{6} \mathrm{~N}_{5} \mathrm{P}, 709.2769$; found, 709.3631; ${ }^{1} \mathrm{H}$ NMR (400 MHz, DMSO-d $\left.d_{6}\right) \delta 1.37\left(\mathrm{~s}, 12 \mathrm{H}, \mathrm{CH}_{3}\right), 3.18\left(\mathrm{~s}, 8 \mathrm{H}, \mathrm{CH}_{2}\right.$ ), $3.87\left(\mathrm{~d}, J=6.4 \mathrm{~Hz}, 8 \mathrm{H}, \mathrm{CH}_{2}\right), 4.08\left(\mathrm{t}, J=3.2 \mathrm{~Hz}, 12 \mathrm{H}, \mathrm{CH}_{2}\right)$, 6.50 (q, $J=2.0 \mathrm{~Hz}, 4 \mathrm{H}, \operatorname{Ar} H), 6.94(\mathrm{~d}, J=4.4 \mathrm{~Hz}, 4 \mathrm{H}, \operatorname{Ar} H)$, 7.05 (s, 4H, ArH), $7.23(\mathrm{~m}, 4 \mathrm{H}, \operatorname{Ar} H), 7.40(\mathrm{t}, J=8.4 \mathrm{~Hz}, 8 \mathrm{H}$, $\operatorname{Ar} H$ ), 7.45 (s, 4H, ArH), 7.51 (s, 4H, ArH), 8.69 ppm (s, 4H, $\mathrm{NCHN}) ;{ }^{13} \mathrm{C}$ NMR (100 MHz, DMSO-d 6 ) $\delta 152.2(\mathrm{NCN})$, 134.1 (ArC), 130.7 (ArC), $130.6(\operatorname{ArC}), 129.1(\operatorname{ArC}), 128.1$ $(\mathrm{ArC}), 127.6(\mathrm{ArC}), 124.8(\mathrm{ArC}), 124.4(\mathrm{ArC}), 123.4(\mathrm{ArC})$, $120.5(\mathrm{ArC}), 107.9(\mathrm{ArC}), 106.8(\mathrm{ArC}), 48.5\left(\mathrm{CH}_{2}\right), 46.7$ $\left(\mathrm{CH}_{2}\right), 46.6\left(\mathrm{CH}_{2}\right), 38.9(\mathrm{CH} 2), 11.9 \mathrm{ppm}\left(\mathrm{CH}_{2}\right)$.

\section{Fluorescence titrations}

The concentration of $\mathbf{3}$ and the guest ions was $5.0 \cdot 10^{-6}$ and $0.0-45.0 \cdot 10^{-5} \mathrm{M}$, respectively, in the sample solutions. The excitation wavelength was set to $\lambda_{\mathrm{ex}}=258 \mathrm{~nm}$ and the widths of the emission and excitation spectral lines were adjusted to 5 and $10 \mathrm{~nm}$. The emission spectra were recorded in the range of $375-500 \mathrm{~nm}$. The program Origin 8.0 was employed for data processing.

\section{UV-vis titrations}

For UV-vis titrations, the sample solutions were prepared analogously to fluorescence titrations. The concentration of $\mathbf{3}$ was adjusted to $1.0 \cdot 10^{-6} \mathrm{M}$ while the concentration of $\mathrm{Cr}^{3+}$ ranged between 0.0 and $36.0 \cdot 10^{-6} \mathrm{M}$. The absorption spectra were recorded at 240-300 $\mathrm{nm}$. Origin 8.0 was employed for data processing.

\section{X-ray analysis}

Diffraction data of $\mathbf{3}$ were collected by a Bruker Apex II CCD diffractometer [56]. SHELXS was used to solve the structure of 3 [57]. Other crystallographic data are shown in Supporting Information File 1, Table S1. 


\section{Supporting Information}

\section{Supporting Information File 1}

Supporting crystallographic data, fluorescence, UV,

HRMS, and IR spectra of $\mathbf{3}$ and $\mathbf{3} \cdot \mathrm{Cr}^{3+}$, general considerations, characterization data, and copies of the ${ }^{1} \mathrm{H}$ and ${ }^{13} \mathrm{C}$ NMR spectra of all compounds.

[https://www.beilstein-journals.org/bjoc/content/ supplementary/1860-5397-15-278-S1.pdf]

\section{Acknowledgements}

Financial support for this work was received from Tianjin Natural Science Foundation (No. 18JCZDJC99600), the National Natural Science Foundation of China (No. 21572159), and the Program for Innovative Research Team at the University of Tianjin (TD13-5074).

\section{ORCID ${ }^{\circledR}$ iDs}

Qing-Xiang Liu - https://orcid.org/0000-0001-7824-3318

\section{Preprint}

A non-peer-reviewed version of this article has been previously published as a preprint doi:10.3762/bxiv.2019.81.v1

\section{References}

1. Lee, M. H.; Kim, J. S.; Sessler, J. L. Chem. Soc. Rev. 2015, 44, 4185-4191. doi:10.1039/c4cs00280f

2. Carter, K. P.; Young, A. M.; Palmer, A. E. Chem. Rev. 2014, 114, 4564-4601. doi:10.1021/cr400546e

3. Zhang, X.; Yin, J.; Yoon, J. Chem. Rev. 2014, 114, 4918-4959. doi:10.1021/cr400568b

4. Kim, H. N.; Ren, W. X.; Kim, J. S.; Yoon, J. Chem. Soc. Rev. 2012, 41, 3210-3244. doi:10.1039/c1cs15245a

5. Li, Z.; Yu, M.; Zhang, L.; Yu, M.; Liu, J.; Wei, L.; Zhang, H. Chem. Commun. 2010, 46, 7169-7171. doi:10.1039/c0cc01687j

6. Jiao, X.; Huang, K.; He, S.; Liu, C.; Zhao, L.; Zeng, X. Org. Biomol. Chem. 2019, 17, 108-114. doi:10.1039/c8ob02583e

7. Jiao, X.; Liu, C.; He, S.; Zhao, L.; Zeng, X. Dyes Pigm. 2019, 160, 86-92. doi:10.1016/j.dyepig.2018.07.040

8. Cheng, J.; Yang, E.; Ding, P.; Tang, J.; Zhang, D.; Zhao, Y.; Ye, Y. Sens. Actuators, B 2015, 221, 688-693. doi:10.1016/j.snb.2015.07.003

9. Arakawa, H.; Ahmad, R.; Naoui, M.; Tajmir-Riahi, H.-A. J. Biol. Chem. 2000, 275, 10150-10153. doi:10.1074/jbc.275.14.10150

10. Anderson, R. A. Regul. Toxicol. Pharmacol. 1997, 26, S35-S41. doi:10.1006/rtph.1997.1136

11. Vincent, J. B. Nutr. Rev. 2000, 58, 67-72. doi:10.1111/j.1753-4887.2000.tb01841.x

12. Vincent, J. B. Proc. Nutr. Soc. 2004, 63, 41-47. doi:10.1079/pns2003315

13. Costa, M.; Klein, C. Crit. Rev. Toxicol. 2006, 36, 779. doi:10.1080/10408440600932169

14. Dai, R.; Yu, C.; Liu, J.; Lan, Y.; Deng, B. Environ. Sci. Technol. 2010, 44, 6959-6964. doi:10.1021/es100902y
15. Tang, Y.; Liu, L.; Zhang, Y.; Zhao, H.; Kong, L.; Gao, S. New J. Chem. 2018, 42, 19340-19343. doi:10.1039/c8nj04398a

16. Raju, V.; Selva Kumar, R.; Ashok Kumar, S. K.; Tharakeswar, Y.; Sahoo, S. K. Inorg. Chem. Commun. 2019, 101, 74-80. doi:10.1016/j.inoche.2019.01.011

17. Wu, S.; Zhang, K.; Wang, Y.; Mao, D.; Liu, X.; Yu, J.; Wang, L. Tetrahedron Lett. 2014, 55, 351-353. doi:10.1016/j.tetlet.2013.11.024

18. Shahim, S.; Sukesan, R.; Sarangadharan, I.; Wang, Y.-L. Sensors 2019, 19, 1969-1982. doi:10.3390/s19091969

19. Yin, H.; Zhao, B.; Kan, W.; Liu, T.; Wang, W.; Yin, G.; Wang, L.; Gao, Y.; Wang, J. Spectrochim. Acta, Part A 2019, 217, 18-26. doi:10.1016/j.saa.2019.03.060

20. Zhang, M.; Gong, L.; Sun, C.; Li, W.; Chang, Z.; Qi, D. Spectrochim. Acta, Part A 2019, 214, 7-13. doi:10.1016/j.saa.2019.01.089

21. Sutariya, P. G.; Soni, H.; Gandhi, S. A.; Pandya, A. J. Lumin. 2019, 208, 6-17. doi:10.1016/j.jlumin.2018.12.009

22. Koonrugsa, N.; Fuangswasdi, S. Spectrochim. Acta, Part A 2019, 215, 15-23. doi:10.1016/j.saa.2019.02.052

23. Zhang, T.; Mu, L.; She, G.; Shi, W. J. Lumin. 2019, 209, 267-273. doi:10.1016/j.jlumin.2019.01.055

24. Zhu, H.; Fan, J.; Wang, B.; Peng, X. Chem. Soc. Rev. 2015, 44, 4337-4366. doi:10.1039/c5cs90058a

25. Shirinfar, B.; Ahmed, N.; Park, Y. S.; Cho, G.-S.; Youn, I. S.; Han, J.-K.; Nam, H. G.; Kim, K. S. J. Am. Chem. Soc. 2013, 135, 90-93. doi:10.1021/ja3112274

26. Lim, N. C.; Pavlova, S. V.; Brückner, C. Inorg. Chem. 2009, 48 , 1173-1182. doi:10.1021/ic801322x

27. Xu, M.; Wu, S.; Zeng, F.; Yu, C. Langmuir 2010, 26, 4529-4534. doi:10.1021/la9033244

28. Weerasinghe, A. J.; Schmiesing, C.; Varaganti, S.; Ramakrishna, G.; Sinn, E. J. Phys. Chem. B 2010, 114, 9413-9419. doi:10.1021/jp1034568

29. Goswami, S.; Aich, K.; Das, S.; Das, A. K.; Sarkar, D.; Panja, S.; Mondal, T. K.; Mukhopadhyay, S. Chem. Commun. 2013, 49, 10676-10678. doi:10.1039/c3cc46860g

30. Mahato, P.; Saha, S.; Suresh, E.; Di Liddo, R.; Parnigotto, P. P.; Conconi, M. T.; Kesharwani, M. K.; Ganguly, B.; Das, A. Inorg. Chem. 2012, 51, 1769-1777. doi:10.1021/ic202073q

31. Liu, C.; Pan, J.; Li, S.; Zhao, Y.; Wu, L. Y.; Berkman, C. E.; Whorton, A. R.; Xian, M. Angew. Chem., Int. Ed. 2011, 50, 10327-10329. doi:10.1002/anie.201104305

32. Choi, M. G.; Cha, S.; Lee, H.; Jeon, H. L.; Chang, S.-K. Chem. Commun. 2009, 7390-7392. doi:10.1039/b916476f

33. Sasakura, K.; Hanaoka, K.; Shibuya, N.; Mikami, Y.; Kimura, Y.; Komatsu, T.; Ueno, T.; Terai, T.; Kimura, H.; Nagano, T. J. Am. Chem. Soc. 2011, 133, 18003-18005. doi:10.1021/ja207851s

34. Zhang, L.; Lou, X.; Yu, Y.; Qin, J.; Li, Z. Macromolecules 2011, 44, 5186-5193. doi:10.1021/ma200777e

35. Cao, X.; Lin, W.; He, L. Org. Lett. 2011, 13, 4716-4719. doi:10.1021/ol201932c

36. Zhang, H.; Sun, T.; Ruan, Q.; Zhao, J.-L.; Mu, L.; Zeng, X.; Jin, Z.; Su, S.; Luo, Q.; Yan, Y.; Redshaw, C. Dyes Pigm. 2019, 162, 257-265. doi:10.1016/j.dyepig.2018.10.025

37. Mabhai, S.; Dolai, M.; Dey, S. K.; Dhara, A.; Choudhury, S. M.; Das, B.; Dey, S.; Jana, A. Spectrochim. Acta, Part A 2019, 219, 319-332. doi:10.1016/j.saa.2019.04.056

38. Hosseini, M.; Khoobi, M.; Tarasi, R.; Ganjali, M. R. Res. Chem. Intermed. 2018, 44, 5031-5042. doi:10.1007/s11164-018-3407-z 
39. Jang, H. J.; Kang, J. H.; Yun, D.; Kim, C. J. Fluoresc. 2018, 28 , 785-794. doi:10.1007/s10895-018-2240-5

40. Singh, J.; Kaur, V.; Singh, R.; Bhardwaj, V. K. Spectrochim. Acta, Part A 2018, 201, 46-53. doi:10.1016/j.saa.2018.04.056

41. Miller, M. W.; Amidon, R. W.; Tawney, P. O. J. Am. Chem. Soc. 1955, 77, 2845-2848. doi:10.1021/ja01615a053

42. Verlinden, K.; Ganter, C. J. Organomet. Chem. 2014, 750, $23-29$. doi:10.1016/j.jorganchem.2013.10.047

43. Pickering, A. L.; Seeber, G.; Long, D.-L.; Cronin, L. CrystEngComm 2005, 7, 504-510. doi:10.1039/b506718a

44. Upadhyay, Y.; Paira, P.; Ashok Kumar, S. K.; Choi, H.-J.; Kumar, R.; Sahoo, S. K. Inorg. Chim. Acta 2019, 489, 198-203. doi:10.1016/j.ica.2019.02.028

45. Adhikari, S.; Ta, S.; Ghosh, A.; Guria, S.; Pal, A.; Ahir, M.; Adhikary, A.; Hira, S. K.; Manna, P. P.; Das, D. J. Photochem. Photobiol., A 2019, 372, 49-58. doi:10.1016/j.jphotochem.2018.12.010

46. Jin, H.; Xu, J.; Zhang, L.; Ma, B.; Shi, X.; Fan, Y.; Wang, L. J. Solid State Chem. 2018, 268, 168-174. doi:10.1016/j.jssc.2018.08.035

47. Liu, Q.-X.; Yao, Z.-Q.; Zhao, X.-J.; Zhao, Z.-X.; Wang, X.-G. Organometallics 2013, 32, 3493-3501. doi:10.1021/om400277z

48. Goswami, S.; Hazra, A.; Chakrabarty, R.; Fun, H.-K. Org. Lett. 2009, 11, 4350-4353. doi:10.1021/ol901737s

49. Ulatowski, F.; Dąbrowa, K.; Bałakier, T.; Jurczak, J. J. Org. Chem. 2016, 81, 1746-1756. doi:10.1021/acs.joc.5b02909

50. Arunkumar, E.; Ajayaghosh, A.; Daub, J. J. Am. Chem. Soc. 2005, 127, 3156-3164. doi:10.1021/ja045760e

51. Thordarson, P. Chem. Soc. Rev. 2011, 40, 1305-1323. doi:10.1039/c0cs00062k

52. Caballero, A.; Martínez, R.; Lloveras, V.; Ratera, I.; Vidal-Gancedo, J.; Wurst, K.; Tárraga, A.; Molina, P.; Veciana, J. J. Am. Chem. Soc. 2005 127, 15666-15667. doi:10.1021/ja0545766

53. Li, S.; Zhang, D.; Xie, X.; Ma, S.; Liu, Y.; Xu, Z.; Gao, Y.; Ye, Y. Sens. Actuators, B 2016, 224, 661-667. doi:10.1016/j.snb.2015.10.086

54. Braga, D.; Costa, A. L.; Grepioni, F.; Scaccianoce, L.; Tagliavini, E. Organometallics 1997, 16, 2070-2079. doi:10.1021/om9603878

55. Foster, N. R.; Grieves, G. A.; Buchanan, J. W.; Flynn, N. D.; Duncan, M. A. J. Phys. Chem. A 2000, 104, 11055-11062. doi:10.1021/jp002131s

56. SAINT Software Reference Manual (SMART 5.0 and SAINT 4.0 for Windows NT); Bruker Analytical X-ray Systems Inc.: Madison, WI, USA, 1998.

57. Sheldrick, G. M. Acta Crystallogr., Sect. C: Struct. Chem. 2015, 71, 3-8. doi:10.1107/s2053229614024218

\section{License and Terms}

This is an Open Access article under the terms of the Creative Commons Attribution License (http://creativecommons.org/licenses/by/4.0). Please note that the reuse, redistribution and reproduction in particular requires that the authors and source are credited.

The license is subject to the Beilstein Journal of Organic Chemistry terms and conditions: (https://www.beilstein-journals.org/bjoc)

The definitive version of this article is the electronic one which can be found at:

doi:10.3762/bjoc. 15.278 